\title{
Detecting fraudulent financial statements in pharmaceutical companies: Fraud pentagon theory perspective
}

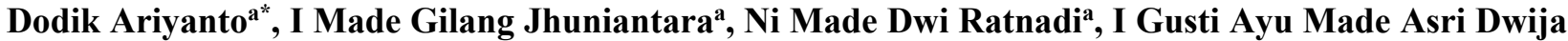 \\ Putri $^{\mathrm{a}}$ and Ayu Aryista Dewi ${ }^{\mathrm{a}}$
}

\section{${ }^{a}$ Faculty of Economics and Business, Universitas Udayana, Bali, Indonesia \\ C H R O N I C L E \\ A B S T R A C T}

Article history:

Received: February 27, 2021

Received in revised format:

April 292021

Accepted: May 16, 2021

Available online:

May 18, 2021

Keywords:

Fraud

Financial statement

Pharmaceutical companies

Covid-19 pandemic

\begin{abstract}
A fraudulent financial statement is an issue that continues to be discussed as a form of deviation from corporate governance. Covid-19 pandemic has also demanded management to uphold the company's performance to have a good public image. Thus, the present study sets out to scrutinize the fraud pentagon theory on fraudulent financial statements. Each element is not able to be tested directly. However, there are proxies. The pressure element is proxied as a personal financial need. The opportunity is becoming the nature of industry. Each of the qualities of the external auditors as well as the change of directors propose rationalization and competence. The frequent number of CEO's appearances in photos is a proxy of arrogance. The testing was carried out on the registered pharmaceutical companies of the Indonesian stock exchange in the span of the 2015-2019 period. The samples were selected by the means of sampling technique which is purposive. Data are scrutinized by the means of panel data regression. The analysis results show that the characteristics of the industry positively affects financial reports which are fraudulent. Changing top management positions such as directors can be an indication of financial reports which are fraudulent. The personal financial need variables, the caliber of external auditors and the quantity of CEO's appearance in photos pose no effects on the fraudulent financial statements of the Indonesian's pharmaceutical companies.
\end{abstract}

\section{Introduction}

The pandemic of COVID 19 causes a slowdown in various sectors of the economy (Donthu \& Gustafsson, 2020; Hadiwardoyo, 2020; Sigala, 2020). Seetharaman (2020) stated that the pandemic impacts caused widespread business stoppages and a temporary decline in the aggregate supply of consumption and investment reduced demand for goods and services. These caused the company to take steps to maintain the company's performance. High pressure in maintaining image and performance, has caused the company to do everything possible for them (Ariyanto et al., 2020). One of the illegal ways that can be done is by manipulating the financial reports (Rengganis et al., 2019; Rukmana, 2018; Septriyani \& Handayani, 2018). Financial statement manipulation has occurred in several companies before the pandemic took place (Vivianita \& Indudewi, 2019; Yateno \& Sari, 2016). This manipulation has even occurred in a sector that was experiencing a surge in sales during a pandemic, namely the pharmaceutical industry. The pharmaceutical company that was proven to have manipulated financial statements was PT Kimia Farma in 2002. The manipulation occurred in some units; namely, the raw material industry that experienced $\mathrm{Rp} 2.7$ billion worth of overstated sales, there was also $\mathrm{Rp} 23.9$ billion worth of overstated inventory in the central logistics unit, $\operatorname{Rp} 8.1$ billion worth of overstated inventory and $\mathrm{Rp} 10.7$ billion worth of overstated sale in the pharmaceutical

\footnotetext{
* Corresponding author.

E-mail address: dodikariyanto@unud.ac.id (D. Ariyanto) 
wholesaler unit (Pasaribu \& Kharisma, 2018). These cases also proved that the pharmaceutical industry was an industry that was prone to manipulation, especially in the supply sector (Putriana et al., 2018).

Previous studies on the fraud pentagon theory were conducted on several types of companies in Indonesia, such as manufacturing companies (Agusputri \& Sofie, 2019; Kurnia \& Anis, 2017; Setiawati \& Baningrum, 2018), food and beverage subsector (Triyanto, 2019) and the banking industry (Hidayah \& Saptarini, 2019; Saputra \& Kesumaningrum, 2017; Tessa, 2016). This research fills the research gap by testing it in the pharmaceutical industry in Indonesia. Since there has been no similar research examining the fraud pentagon theory, this study was held in the pharmaceutical industry in Indonesia. Another reason for choosing the pharmaceutical industry is because this industry has experienced an increase in sales during a pandemic and has become a business that tends to be profitable. This is because the license to produce the covid-19 vaccine is given to pharmaceutical companies. As a form of social responsibility, pharmaceutical companies should be free from fraud scandals to gain the trust of the public (Rahayu et al., 2019). This is quite reasonable considering that the covid-19 vaccine is related to the health and livelihoods of many people. Therefore, it is necessary to identify a theory that would be used to predict indications of fraudulent financial statements. Early predictions are needed by regulators to set rules and to prevent pharmaceutical companies, as covid-19 vaccine producers, from fraudulent financial reports.

\section{Literature review and hypotheses formulation}

An agency relationship is a contract in which one or more people (principal) order another person (agent) to perform a service on behalf of the principal and authorize the agent to make the best decisions for the principal. If both parties have the same goal of maximizing company value, it is believed that the agent will act in a manner consistent with the principal's interests. Agency theory describes the relationship between shareholders as the principal and management as the agent. Management is a party contracted by shareholders to work for the interests of shareholders. Because they are elected, the management must be accountable for all of its work to the shareholders (Jensen \& Meckling, 1976). The latest development of the fraud model is the fraud pentagon. It is developed from the fraud triangle as well as the fraud diamond theories. Fraud triangle theory is a theory put forward by Donald R. Cressey in his dissertation in 1953 on respondents who were fraud perpetrators based on court decisions. Cressey (1953) stated that the act of fraud was inspired by three facets, i.e., pressure, opportunity as well as rationalization (Ariyanto et al., 2020; Bujaki et al., 2019; Kanten \& Ulker, 2013). Wolfe and Hermanson (2004) proposed the fraud diamond theory as a new viewpoint on the cases of fraud. The theory was built on Cressey's fraud triangle theory (1953). In addition to the pressure elements, the opportunity elements and the rationalization elements, Wolfe \& Hermanson (2004) added a qualitative element which they believed could influence fraud, namely the capability elements. As such, the new theory explains that the four elements affect a person to commit fraud. Marks (2012) added two elements, namely competence (competence) and arrogance (arrogance). The competence which he proposed and the capabilities put forward by Wolfe and Hermanson in their fraud diamond theory are very similar. Crowe Howarth defined competence or capability as "the employees' ability to ignore internal controls, develop concealment strategies, and control social situations for their gain" (Tessa, 2016). Arrogance is defined as an attitude stemming from superiority or an arrogant nature in those who hold that internal control cannot be enforced personally (Apriliana \& Agustina, 2017). This arrogance arises from the belief that he can do cheating and that the control cannot befall him (Danuta, 2017; Tugas, 2012).

Beasley (1996) argues that when the executives in the company show great financial interest in the institution's welfare, then the company's financial performance will influence their personal financial situations. Good company's performance will be beneficial for the personal financial needs of the executives, especially those who own shares in the company. However, when the company's performance is bad, the personal financial needs of these executives will be adversely affected. With an attitude towards what is owned, where executives want to ensure that their financial condition is good, it is within the interest of the company executives to ensure that the company's performance will remain good by not taking actions that can harm it, one of which indicates a fraud (Siddiq et al., 2017). Kusumaningsih and Wirajaya, (2017); Yusof et al. (2015) states that the executive will tend to take action to maintain his financial condition. Thus, personal financial need is thought to trigger indications of fraud. Aprilia (2017) found that the pressure experienced by company executives was able to influence the chances of fraud. Kusumaningsih and Wirajaya (2017) revealed that financial personal need has negative effects on fraud. The research is in line with Kusumaningrum and Murtanto (2016) who found that insider stock ownership negatively affects the detection of financial reports which are fraudulent. As such, the first hypothesis is prepared, namely, the better the personal financial welfare or shared ownership of insiders, the lower the occurrence of financial reports which are fraudulent.

\section{$\mathbf{H}_{1}$ : Personal financial needs have negative effects on indications of financial reports which are fraudulent.}

There exist particular accounts whose balance is governed by the company contingent on an approximation, for instance, accounts receivable as well as obsolete inventory (Suparmini et al., 2020; Tiffani \& Marfuah, 2015). Sihombing \& Rahardjo (2014) explained that there is an element of subjectivity in determining the worth of the accounts in the financial statements which results in management being able to use the accounts as a way to manipulate financial reports. Accrual discretion requires strict internal control or supervision of the company (Sunardi \& Amin, 2018). Weak controls will provide a great opportunity for fraud to occur (Wicaksono, 2015). Inventory conditions are a manifestation of the characteristics of the industry which could be answered by various feedbacks which the company managers provided. The characteristics of the industry is defined as the ideal condition for a company operating in the line business (Septriyani \& Handayani, 2018; Sunardi \& 
Amin, 2018). The situation of the company's inventory is an aspect in the characteristics of the industry. A good company tends to restrain and reduce the company's inventory while raising the company's cash flow receipts (Skousen et al., 2009). Skousen et al. (2009) measure the characteristics of the industry by the means of the ratio of changes in total inventories as well as in total accounts receivable. Previous research carried out by Yendrawati et al. (2019); Putriasih (2016); Siddiq et al. (2017) also revealed how the industry's characteristics positively influences the detection of financial reports which are fraudulent. Hence, the second hypothesis can be formulated, namely the higher the characteristics of the industry or the perfect condition of a company operating in the industry, the lower the occurrence of financial reports which are fraudulent.

\section{$\mathbf{H}_{2}$ : The nature of industry positively affects the indications of financial reports which are fraudulent.}

Chen et al. (2005) stated that companies whose audits are completed by reputable public accounting firms are less likely to commit fraud before the IPO process when juxtaposed with institutions whose audits are carried out by Big 4 public accounting firms. This shows that choosing a public accounting firm belonging to the Big 4 is a barrier for companies to cheating (Suparmini et al., 2020). Chen (2016) in his research showed that the Big 4 auditing firms reduce the incidence of financial scandals in foreign companies. Weiner (2012) stated that the size of the auditor's company indicates credibility and is followed by the disclosure of corporate fraud. Likewise expressed by Fimanaya \& Syafruddin (2014); Noor et al. (2015) that the size of the auditing firms has affected the possibility of manipulation of the financial statements. Provided the explanation above, the third hypothesis of this study can be drawn up, namely, the better the caliber of the independent auditors, the smaller the occurrence of financial reports which are fraudulent.

\section{H3: The quality of external auditors negatively affects the indications which marks financial reports which are fraudulent.}

Altering the makeup of the board of directors is intended to improve corporate governance for the better (Annisya et al., 2016a). Suparmini et al. (2020) stated that changing top management positions such as directors could be seen as an effort to remove directing officials who were deemed to have knowledge of the fraud perpetrated by the institution. Thus, the change of directors was deemed to demand time to adapt so that initial performance was not optimal. Manurung and Hardika (2015) use the change of directors as variables to determine the potential for financial statement fraud. They managed to prove that altering the makeup of the board of directors significantly and positively affects the potential for financial reports which are fraudulent. This research is supported by Nurbaiti \& Hanafi (2017) stating that changing top management poses a notable effect on accounting irregularities. Moreover, a research by Mardiani et al. (2017) disclosed that the changing top management positions such as directors brings about influences on financial reports which are fraudulent. Thus, the fourth hypothesis for this study can be formulated as follows, the more frequent top management positions such as directors change, the higher the occurrence of financial reports which are fraudulent becomes.

H4: Change in directors positively affects the indications of financial reports which are fraudulent.

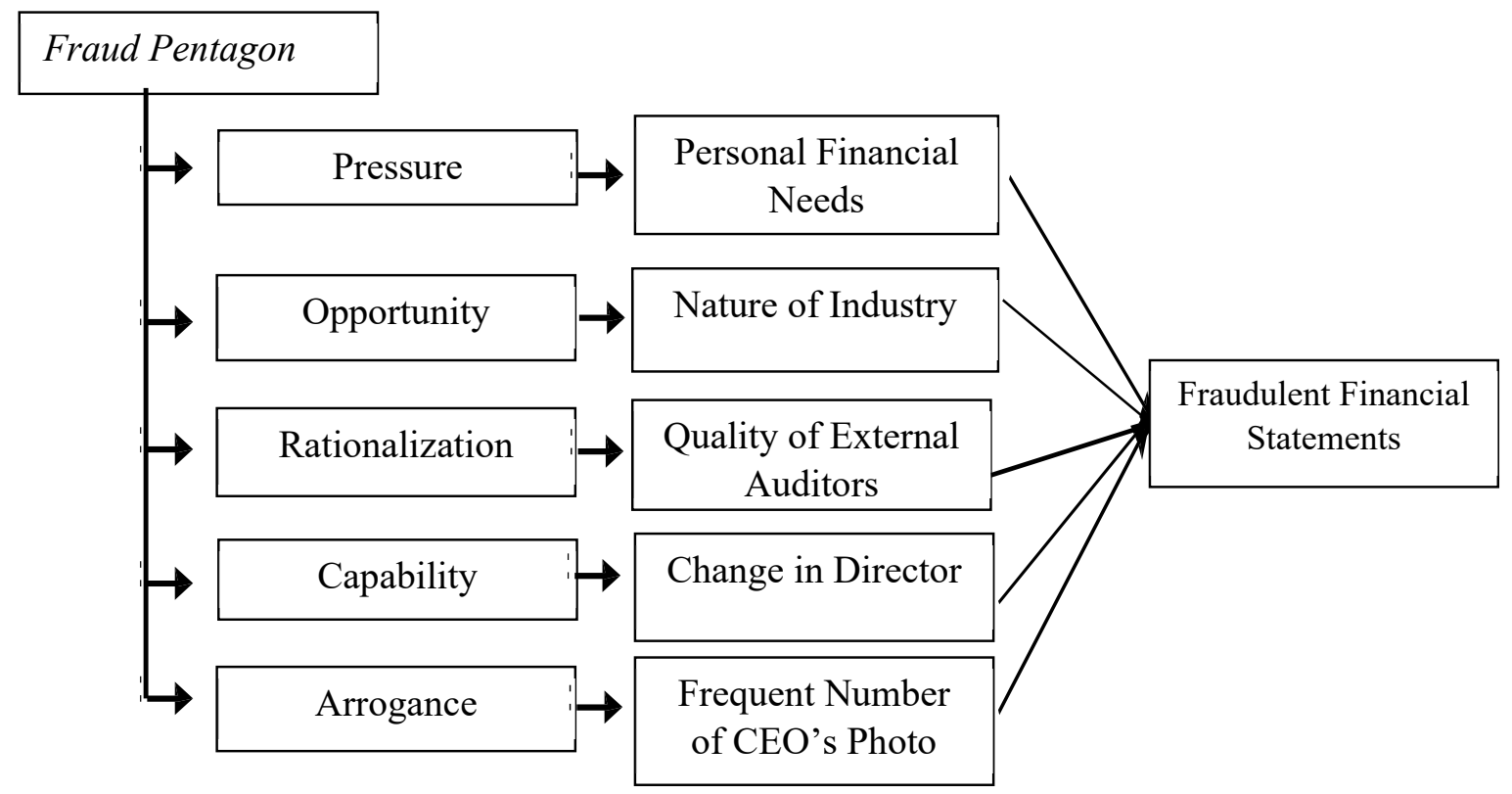

Fig. 1. Research Model

Fraud can also be preceded by strong arrogance because a CEO's feeling of superiority may lead them to feel that they are immune to any internal controls due to their status and position (Tessa, 2016). One measure of arrogance can be seen from 
the frequency with which CEO photos appear in company annual reports (Buchholz et al., 2019). If a CEO has enough photos in the company's yearly statement, the CEO is considered to have a desire to be known by the wider community (Yusof, 2015). This is assessed as the presence of arrogance in the CEO (Yusof, 2015). This agrees with a study carried out by Bawakes et al. (2018); Setiawati \& Baningrum (2018) which show fraudulent financial reports are significantly affected by how often the images of the CEO appear. This is because the amount of the CEO's photos shown in the yearly reports of an institution can suggest how arrogant and superior they may be perceived. However, this is not supported by research by Sasongko \& Wijayantika (2019); Ulfah et al. (2017); Vivianita \& Indudewi (2019) which indicate that how often the CEO's images appear bears no effects on the reporting of financial reports which are fraudulent. The frequency of appearance of the CEO image is used to measure arrogance which is included in the fraud pentagon element.

\section{Hs: The frequent number of CEO photos indicates the financial reports which are fraudulent.}

\section{Research method}

The present research was carried out on pharmaceutical companies registered on the Indonesia Stock Exchange (BEI) during the span of 2015-2019 by accessing the official website of Indonesia's stock exchange (IDX), namely www.idx.co.id. The yearly reports of these pharmaceutical institutions during the aforementioned period serves as the object of study in the present research. This effort focuses on information related to financial reports which are fraudulent, personal financial needs, characteristics of the industry, independent auditor's qualifications, changing of top management positions such as directors and displays of CEO photos. All pharmaceutical institutions registered on the IDX serve as the population in the present study. The sample used is a pharmaceutical company registered on the IDX selected through a technique of sampling which is purposive, with the criteria of publishing consecutive reports during the 2015-2019 period and not delisting during the 20152019 period. Based on documentary observations, there are 10 pharmaceutical institutions registered on the Indonesia Stock Exchange (IDX) with two companies that did not issue reports consecutively, namely PT Phapros Tbk and PT Merck Sharp Dohme Pharma Tbk. There were as many as 8 companies which could be sampled with 5 years of observation. Thus, 40 samples were obtained. Examining financial reports which are fraudulent in the present study involves using the fraud score model put forward by Dechow et al. (2012). Skousen et al. explained that "the F-score model is the sum of two variables, i.e., the accrual quality and financial performance" (2009). The variable of personal financial condition is proxied by insider ownership of shares (OSHIP). OSHIP proxy is the cumulative percentage of ownership in a company owned by an insider, calculated by the shares owned by the insider with the number of shares outstanding. The present study uses the total inventory that is divided by the sum sales of the research year minus the total inventory divided by the sum sales of the previous year as a proxy for the nature of the industry. Furthermore, the quality of independent auditors is measured using an ordinal scale (dummy variable), namely by providing code 1 for companies audited by the Big Four involved, namely Ernst \& Young, Deloitte Touche Tohmatsu, KPMG and Pricewaterhouse Coopers as well as providing code 0 for companies whose audit were not performed by the aforementioned firms. The present study measures the proxy of competence with changes in company directors. This measurement uses an ordinal scale (dummy variable), namely by providing code 1 to mark that there has been a change in directing positions in the company during the observed period. Otherwise, if there has not been a change in directing positions in the company during the observed period, it is coded 0 . Arrogance is proxied by the sum displays of CEO photos on the yearly financial report of the company for the study year. The data analysis performed was panel data regression analysis.

\section{Results}

Before testing the hypothesis, the sample descriptions and descriptions of the research variables, both the dependent and independent variables, are described.

Table 1

Descriptive Statistical Analysis Results

\begin{tabular}{lccccc}
\hline & $\mathrm{Y}$ & $\mathrm{X}_{1}$ & $\mathrm{X}_{2}$ & $\mathrm{X}_{3}$ & $\mathrm{X}_{4}$ \\
\hline Mean & 0.073570 & 0.025785 & 0.040700 & 0.450000 & 0.500000 \\
Maximum & 0.623192 & 0.324000 & 0.807555 & 1.000000 & 1.000000 \\
Minimum & -0.443082 & 0.000000 & -0.165907 & 0.000000 & 0.000000 \\
Std. Dev. & 0.208744 & 0086062 & 0.164623 & 0.503831 & 0.496139 \\
\hline Sour & & &
\end{tabular}

Source: Data processed, 2020

Notes: $\mathrm{Y}=$ fraudulent financial statements, $\mathrm{X}_{1}=$ personal financial need, $\mathrm{X}_{2}=$ nature of industry, $\mathrm{X}_{3}=$ quality of external auditors, $\mathrm{X}_{4}=$ change of directors, $\mathrm{X}_{5}=$ the appearance of the CEO's photo.

On average, 7.35 percent of pharmaceutical companies committed fraudulent financial statements in the period 2015 to 2019 . As much as 2.57 percent of manufacturing company shares in circulation are owned by company insiders such as employees, managers, and directors. The mean for the nature of the industry is 0.040700 . The mean value of the industry's nature is closer to the minimum value, meaning that the average disclosure of total inventory and sales in pharmaceutical institutions tends to be lower. The mean value for the quality of external auditors is 0.450000 . This indicates that the average pharmaceutical company audited by Big 4 auditors is 45 percent. The mean value of change of directors is 0.50000 . The average value of 
change of directors is approaching the maximum value, thus suggesting that the average pharmaceutical company sampled in the 2015-2019 period made a change of directors by 50 percent. The average pharmaceutical company displays 2.9 photos of the CEO in its annual financial statements. The standard deviation of the appearance of the CEO's photo is 1.256777 . This value is located below the average, which means that the data does not fluctuate highly. The assumption test is carried out only on the multicollinearity assumption because there is more than one independent variable and the heteroscedasticity test (Ratnasari \& Solikhah, 2019). The matrix correlation for independent variables showed an absence of high correlation value between independent variables which is not more than 0.80 . This means the data is free from multicollinearity (Ghozali, 2013).

Table 2

Matrix Correlation

\begin{tabular}{|c|c|c|c|c|c|}
\hline & $\mathrm{X}_{1}$ & $\mathrm{X}_{2}$ & $X_{3}$ & $\mathrm{X}_{4}$ & $\mathrm{X}_{5}$ \\
\hline \multicolumn{6}{|l|}{$X_{1}$} \\
\hline $\mathrm{X}_{2}$ & -0.083275 & & & & \\
\hline $\mathrm{X}_{3}$ & -0.075151 & 0.064880 & & & \\
\hline $\mathrm{X}_{4}$ & -0.104432 & -0.196389 & 0.301511 & & \\
\hline $\mathrm{X}_{5}$ & 0.278573 & 0.157945 & 0.225810 & -0.132164 & \\
\hline
\end{tabular}

The outcomes of the heteroscedasticity test indicate the significant value of the personal financial needs variable, the industry's nature, the caliber of the independent auditors, the change of directors and, the number of displays of CEO's photos on the absolute residual variable is above 0.05 . Thus, this suggests that the data analyzed in the present study do not suffer from a heteroscedasticity problem. Having passed the classical assumption test, it is followed by testing the research hypothesis. The present study uses the analysis techniques of panel data regression to test all hypotheses. Selection of the right model for testing the hypothesis is carried out by using the Chow test, Hausman test and Lagrange Multiplier test. Chow test results show a probability value greater than 0.05 . The appropriate model based on the Chow test results is the Common Effect Model. Moreover, the Hausman test results reveal that the probability value is greater than 0.05 . The appropriate model to use based on the Hausman test is the Random Effect Model. Lagrange multiplier test results point to a probability value greater than 0.05 . As such, the appropriate model to use based on the Lagrange multiplier test is the Common Effect Model. Provided the three model tests, the results of the Chow test and the Lagrange multiplier test show the most appropriate Common Effect Model. Thus, the model used to test the Common Effect Model (CEM) hypothesis.

\section{Table 3}

Hypothesis Testing Results with the Common Effect Model

\begin{tabular}{lllll}
\hline Independent Variable & \multicolumn{2}{l}{ Coefficient Value } & T-Statistic value & Probability Value \\
\hline Constant & $\alpha$ & 0.039224 & & \\
Personal Financial Need $\left(\mathrm{X}_{1}\right)$ & $\beta_{1}$ & -0.150234 & -0.455520 & 0.6516 \\
Nature Of Industry $\left(\mathrm{X}_{2}\right)$ & $\beta_{2}$ & 0.387061 & 2.124993 & $0.0409^{* *}$ \\
External Auditor Quality $\left(\mathrm{X}_{3}\right)$ & $\beta_{3}$ & -0.018519 & -0.313438 & 0.7559 \\
Change in Directors $\left(\mathrm{X}_{4}\right)$ & $\beta_{4}$ & 0.198099 & 3.255912 & $0.0026^{* * *}$ \\
Number of CEO Photo Appearance $\left(\mathrm{X}_{5}\right)$ & $\beta_{5}$ & -0.030365 & -1.282349 & 0.2084 \\
\hline Adjusted R-squared & & 0.309391 & & \\
F-statistic & & 4.494384 & & \\
Prob(F-statistic) & & 0.002987 & & \\
\hline Source: Data & & &
\end{tabular}

Source: Data processed, 2020

Information:

*** indicates significant at the level $\alpha=1 \%$

** indicates significant at the level $\alpha=5 \%$

* indicates significant at the level $\alpha=10 \%$

The first hypothesis $\left(\mathrm{H}_{1}\right)$ in the present study states that personal financial need has negative effects on financial reports which are fraudulent. Also, the size of the proportion of shares in pharmaceutical companies owned by insiders does not have an impact on fraudulent financial reports. These results disagree with the hypothesis stating that personal financial needs negatively affect financial reports which are fraudulent. The number of companies which implemented share ownership by company insiders in pharmaceutical companies between 2015 and 2019. This affected the research results.

The second hypothesis $\left(\mathrm{H}_{2}\right)$ in this study states that the characteristics of the industry positively affect financial reports which are fraudulent. The nature of the industry has effects on fraudulent financial statements. The direction of the nature of the industry variable regression coefficient in this study has a positive sign of 0.387061 . The analysis result shows that fraudulent financial statements are positively affected by the nature of the industry. The higher the nature of the industry or the ideal condition of a company in the industry, the higher the indication of the occurrence of fraud in financial statements.

The third hypothesis $\left(\mathrm{H}_{3}\right)$ in the present study argues that the caliber of independent auditors poses negative effects on financial reports which are fraudulent. The size of the auditor company, regardless of Big 4 audit companies or not, had no effects on the fraudulent practice on financial reports. This result disagrees with the hypothesis arguing that the quality of external 
auditors brings about negative effects on fraudulent financial statements. Less than 50 percent of the pharmaceutical companies sampled had their audits performed by any of the Big 4 public accounting firms.

The fourth hypothesis $\left(\mathrm{H}_{4}\right)$ in the present study states that changing directors pose negative effects on financial reports which are fraudulent. The direction of the regression coefficient is positive at 0.198099 , which means that the change of directors increases fraudulent financial statements at pharmaceutical companies. The results of the present study are contingent on the theoretical platform used, namely the fraud pentagon theory.

The analysis results of the panel data regression suggest that the appearance of CEO photos has not affected fraudulent financial reports. This result rejects the sound hypothesis which states that the appearance of the CEO's photo positively affects financial reports which are fraudulent.

\section{Discussion}

The financial condition of the executive who depends on the company causes the executive to maintain the company's financial condition to be looking good. The theory used is not in line with the research results, this is due to the fact that few pharmaceutical companies apply for share ownership by insiders such as employees, managers, directors and commissioners. Some companies that apply for share ownership by company insiders only provide a percentage of less than 2 percent of the total outstanding shares for company insiders so that the personal financial condition of executives is not affected by the company's financial condition. The control function over financial statements that should be carried out by shareholder management cannot always be increased through the large number of share ownership by insiders (Suparmini et al., 2020). Management of non-shareholders will certainly have different profit projections because their financial conditions are not influenced by the company's financial state, insider ownership of shares cannot always reduce fraudulent financial reports.

The findings of the present study also bear resemblance with the findings of a study carried out by Kusumaningrum \& Murtanto (2016); Suparmini et al. (2020) which contend that the characteristics of the industry pose effects on fraudulent financial statements. Sihombing \& Rahardjo (2014) contend that due to subjective judgments in measuring the value of certain accounts, management reserves the power to use the account as a way to exploit financial reports and, to reduce this, tight control or supervision from the internal company is needed. Weak controls will provide a great opportunity for fraud to occur (Donelson et al., 2017). According to Nizar (2017) and Nariman (2015), the Big 4 public accounting firm maintains the true reputation by providing quality audits to increase public trust. Public trust can be increased through the principles contained in the implementation of corporate governance, namely through increased transparency, accountability, responsibility, independence and corporate equality. The results of research that do not support this theory most likely occur because there are factors that influence audit quality more than the public accounting firm size factor. A public accounting firm with a large size but does not have a highly competent auditor is not able to detect fraud properly, as well as auditors who lack independence, the auditor will not be able to provide good audit results. (Suparmini et al., 2020). Pham et al. (2017) found that auditing quality of small public accounting firms tends to be better than large public accounting firms in Vietnam.

The findings of the present study also bear resemblance with the findings of a study carried out by Kusumaningrum \& Murtanto (2016); Suparmini et al. (2020) which contend that the characteristics of the industry poses effects on fraudulent financial statements. Sihombing \& Rahardjo (2014) contend that due to subjective judgments in measuring the value of certain accounts, management reserves the power use the account as a way to exploit financial reports and, to reduce this, tight control or supervision from the internal company is needed. Weak controls will provide a great opportunity for fraud to occur (Donelson et al., 2017). According to Nizar (2017) and Nariman (2015), the Big 4 public accounting firm maintains the true reputation by providing quality audits to increase public trust. Public trust can be increased through the principles contained in the implementation of corporate governance, namely through increased transparency, accountability, responsibility, independence and, corporate equality. The results of research that do not support this theory most likely occur because there are factors that influence audit quality more than the public accounting firm size factor. A public accounting firm with a large size but does not have a highly competent auditor is not able to detect fraud properly, as well as auditors who lack independence, the auditor will not be able to provide good audit results. (Suparmini et al., 2020). Pham et al. (2017) found that auditing quality of small public accounting firms tends to be better than large public accounting firms in Vietnam.

The findings of the present study show inconsistency with the study carried out by Weiner (2012). Weiner stated that the auditor firm size indicates credibility. Thus, it is followed by a disclosure of corporate fraud. This research also disagrees with the study carried out by Fimanaya and Syafruddin (2014) and Huang et al., (2017). Fimanaya and Syafruddin contend that institutions whose audit was performed by any of the Big 4 firms tend not to commit fraud compared to those whose audit was performed by any non-Big 4 firms. Wolfe and Hermanson (2004) found that changing top management positions such as directors may indicate fraud. Making changes in the makeup of the directors is seen as a company's effort to remove directors who are viewed as being aware of fraudulent practices in the company. It is considered that the changing of directors will require some time for adaptation so that the initial performance is not optimal. Besides, the change of directors was often successful because the new directors could use their position to drive the company further and avoid fraud. When going to change the board of directors, the company should select the best possible candidates by judging from the performance in the previous position and their objectives to advance the company (Suparmini et al., 2020). The findings of the present study are 
consistent with the study carried out by Manurung and Hardika (2015) and Mardiani et al. (2017) which contend that the use of the change-of-directors variable to determine the potential for financial statement fraud proves that it has a significant positive effect on the potential for financial statement fraud. The results of this study, however, are not in line with the results of research done by Annisya et al., (2016); Harman \& Bernawati (2020); Suparmini et al. (2020); Zaki (2017) which argue that changes in the makeup of the directors bear no effects on the detection of potential fraudulent financial statements.

The number of photos of the CEO displayed in the yearly report may indicate narcissism, and the CEO may want to show their superiority (Buchholz et al., 2015, 2019; Yusof, 2015). Another purpose of having a CEO photo displayed in the yearly report is to introduce the company's leader. The other photos displayed are mostly photos of the company's activities. Besides, there are still some companies that put only one photo of their CEO in their annual report. Therefore, the number of CEO photos cannot indicate an arrogant attitude and the general nature of the CEO of a company (Agusputri \& Sofie, 2019). These findings are consistent with the study by Bawakes et al. (2018); Husmawati et al. (2017); Sasongko \& Wijayantika (2019); Siddiq et al. (2017) which contend that the frequent number of CEO's images or photos bears no effects on financial reports which are fraudulent.

The findings of the present study are inconsistent with the study by Weiner (2012) which contends that the size of the auditing companies indicates credibility and is followed by disclosure of corporate fraud. Moreover, this research also disagrees with the study carried out by Fimanaya \& Syafruddin (2014); Huang et al., (2017) which argue that institutions whose audit was performed by any of the Big 4 firms tend not to commit fraud compared to those whose audit was performed by any non-Big 4 firms.

\section{Conclusion}

Given the results of the analysis, it can be summarized that personal financial needs, the quality of the independent auditors and the display of the CEO's photo have no effects on the occurrence of fraudulent financial statements. The present study also proves that the characteristics of the industry positively affect the occurrence of financial reports which are fraudulent. This shows that the higher the nature of the industry or the ideal condition of a company in the industry, the more likely it is that financial statement fraud will occur. Meanwhile, the change in the board of directors also positively affects the phenomenon of fraudulent financial statements. This shows that the change of directors at the pharmaceutical companies in the sample indicated that there was fraud in the financial statements. This study offers implications for all shareholders, government, and other parties who need information as a consideration when assessing the opportunity for indications of financial reports which are fraudulent in the company by considering the factors that influence it. The results of this study can also have implications for the company and the management in making disclosures in the company's financial statements. By making disclosures, especially regarding the nature of the industry or ideal conditions and the change in the board of directors in a company, shareholders and other stakeholders, including regulators, can assess the extent to which risks can be managed in the company so as not to cause fraud that is detrimental to many parties. Further research is suggested to use the scope of other sectors, such as the mining sectors, the financial sectors, the banking sectors, and others. For further researchers, other proxies can be used from research variables which are the factors that influence the indications of financial statement fraud in a company.

\section{Acknowledgement}

All authors contributed equally to the conception and design of the study.

\section{References}

Agusputri, H., \& Sofie, S. (2019). Faktor - Faktor Yang Berpengaruh Terhadap Fraudulent Financial Reporting Dengan Menggunakan Analisis Fraud Pentagon. Jurnal Informasi, Perpajakan, Akuntansi, Dan Keuangan Publik, 14(2), 105. https://doi.org/10.25105/jipak.v14i2.5049

Annisya, M., Lindrianasari, \& Asmaranti, Y. (2016a). Pendeteksian Kecurangan Laporan Keuangan Menggunakan Fraud Diamond. Jurnal Bisnis Dan Ekonomi (JBE), 23(1). https://www.unisbank.ac.id/ojs/index.php/fe3/article/view/4307

Annisya, M., Lindrianasari, \& Asmaranti, Y. (2016b). Pendeteksian Kecurangan Laporan Keuangan Menggunakan Fraud Diamond. Jurnal Bisnis Dan Ekonomi (JBE).

Aprilia, A. (2017). Analisis Pengaruh Fraud Pentagon Terhadap Kecurangan Laporan Keuangan Menggunakan Beneish Model Pada Perusahaan Yang Menerapkan Asean Corporate Governance Scorecard. Jurnal ASET (Akuntansi Riset), 9(1), 52-59. https://doi.org/10.17509/jaset.v9i1.5259

Apriliana, S., \& Agustina, L. (2017). The Analysis of Fraudulent Financial Reporting Determinant through Fraud Pentagon Approach. Jurnal Dinamika Akuntansi, 9(2), 154-165. https://doi.org/10.15294/jda.v7i1.4036

Ariyanto, D., Firdaus, G. M., Sari, M. M. R., Dewi, A. A., \& Made Gilang Jhuniantara, I. (2020). How self control and situational pressure influence the tendency to receive gratification: An experimental study. International Journal of Criminology and Sociology, 9, 400-414. https://doi.org/10.6000/1929-4409.2020.09.39

Bawakes, H. F., Simanjuntak, A. M. ., \& Daat, S. C. (2018a). Pengujian Teori Fraud Pentagon Terhadap Fraudulent Financial Reporting. Jurnal Akuntansi \& Keuangan Daerah, 13(1), 114-134. 
Bawakes, H. F., Simanjuntak, A. M. ., \& Daat, S. C. (2018b). Pengujian Teori Fraud Pentagon Terhadap Fraudulent Financial Reporting. Jurnal Akuntansi \& Keuangan Daerah.

Beasley, M. S. (1996). An empirical analysis of the relation between the board of director composition and financial statement fraud. Accounting Review.

Buchholz, F., Jaeschke, R., Lopatta, K., \& Maas, K. (2015). Article information: The Use of Optimistic Tone by Narcissistic CEOs. Accounting, Auditing \& Accountability Journal, 31(2), 531-562. https://doi.org/10.1108/AAAJ-11-2015-2292

Buchholz, F., Lopatta, K., \& Maas, K. (2019). The Deliberate Engagement of Narcissistic CEOs in Earnings Management. Journal of Business Ethics. https://doi.org/10.1007/s10551-019-04176-x

Bujaki, M., Lento, C., \& Sayed, N. (2019). Utilizing professional accounting concepts to understand and respond to academic dishonesty in accounting programs. Journal of Accounting Education, 47, 28-47. https://doi.org/10.1016/j.jaccedu.2019.01.001

Chen, K. Y., Lin, K. L., \& Zhou, J. (2005). Audit quality and earnings management for Taiwan IPO firms. Managerial Auditing Journal, 20(1), 86-104. https://doi.org/10.1108/02686900510570722

Chen, L. (2016). Local Institutions, Audit Quality, and Corporate Scandals of US-Listed Foreign Firms. Journal of Business Ethics, 133(2), 351-373. https://doi.org/10.1007/s10551-014-2370-x

Chong, G. (2006). Is income smoothing ethical? Journal of Corporate Accounting \& Finance, 18(1), 41-44. https://doi.org/10.1002/jcaf.20261

Cressey, D. (1953). Other People's Money: A Study in The Social Psychology of Embezzlement. Free Press.

Danuta, K. S. (2017). Crowe's Fraud Pentagon Theory dalam Pencegahan Fraud pada Proses Pengadaan melalui E-Procurement. Jurnal Kajian Akuntansi, 1(2), 826. https://doi.org/10.33603/jka.v1i2.826

Dechow, P. M., Hutton, A. P., Kim, J. H., \& Sloan, R. G. (2012). Detecting Earnings Management: A New Approach. Journal of Accounting Research, 50(2), 275-334. https://doi.org/10.1111/j.1475-679X.2012.00449.x

Donelson, D. C., Ege, M. S., \& McInnis, J. M. (2017). Internal control weaknesses and financial reporting fraud. Auditing, 36, 45-69. https://doi.org/10.2308/ajpt-51608

Donthu, N., \& Gustafsson, A. (2020). Effects of COVID-19 on business and research. Journal of Business Research, 284289. https://doi.org/10.1016/j.jbusres.2020.06.008

Fimanaya, F., \& Syafruddin, M. (2014). Analisis Faktor-Faktor Yang Mempengaruhi Kecurangan Laporan Keuangan (Studi Empiris pada Perusahaan Non Keuangan yang Terdaftar di Bursa Efek Indonesia Tahun 2008-2011). Diponegoro Journal Of Accounting, 3(99), 397-407. http://ejournal-s1.undip.ac.id/index.php/accounting

Hadiwardoyo, W. (2020). Kerugian Ekonomi Nasional Akibat Pandemi Covid-19. Baskara Journal of Business and Enterpreneurship, 2(2), 83-92. https://doi.org/10.24853/baskara.2.2.83-92

Harman, S. A., \& Bernawati, Y. (2020). Determinants of Financial Statement Fraud: Fraud Pentagon Perspective in Manufacturing Companies. International Journal of Innovation, Creativity and Change, 13(4), 1453-1472. www.ijicc.net

Hidayah, E., \& Saptarini, G. D. (2019). Pentagon Fraud Analysis in Detecting Potential Financial Statement Fraud of Banking Companies in Indonesia. International Conference on Acoounting, Business, \& Economics, 2010, 89-102.

Huang, S. Y., Lin, C. C., Chiu, A. A., \& Yen, D. C. (2017). Fraud detection using fraud triangle risk factors. Information Systems Frontiers, 19(6), 1343-1356. https://doi.org/10.1007/s10796-016-9647-9

Husmawati, P., Septriani, Y., Rosita, I., \& Handayani, D. (2017). Fraud Pentagon Analysis in Assessing the Likelihood of Fraudulent Financial Statement (Study on Manufacturing Firms Listed in Bursa Efek Indonesia Period 2013-2016). International Conference of Applied Science on Engineering, Business, Linguistics and Information Technology (ICoASCNITech), October, 45-51.

Jensen, M. C., \& Meckling, W. H. (1976). Theory of the Firm: Managerial Behavior, Agency Costs And Ownership Structure. Journal of Financial Economics, 3(4), 305-360. https://doi.org/http://dx.doi.org/10.1016/0304405X(76)90026-X

Kanten, P., \& Ulker, F. (2013). The Macrotheme Review. A Multidisciplinary Journal of Global Macro Trends, 2(4), 144160.

Kim, J. B., Chung, R., \& Firth, M. (2003). Auditor conservatism, asymmetric monitoring, and earnings management. Contemporary Accounting Research, 20(2), 323-359. https://doi.org/10.1506/J29K-MRUA-0APP-YJ6V

Kurnia, A. A., \& Anis, I. (2017). Analisis Fraud Pentagon Dalam Mendeteksi Kecurangan Laporan Keuangan dengan Menggunakan Fraud Score Model. Simposium Nasional Akuntansi XX, Jember.

Kusumaningrum, A. W., \& Murtanto. (2016). Analisis Pengaruh Fraud Diamond Dalam Mendeteksi Kecurangan Laporan Keuangan. Jurnal Akuntansi Dan Bisnis, 2(September), 412-422.

Kusumaningsih, K. U., \& Wirajaya, I. G. A. (2017). Faktor-Faktor Yang Mempengaruhi Tindak Kecurangan Di Perusahaan Perbankan. E-Jurnal Akuntansi, 19(3), 1832-1860.

Manurung, D. T. H., \& Hardika, A. L. (2015). Analysis of factors that influence financial statement fraud in the perspective fraud diamond: Empirical study on banking companies listed on the Indonesia Stock Exchange year 2012 to 2014 . International Conference on Accounting Studies (ICAS).

Mardiani, S., Sukarmanto, E., \& Maemunah, M. (2017). Pengaruh Fraud Diamond Terhadap Pendeteksian Financial Statement Fraud dengan Komite Audit Sebagai Variabel Moderasi. Prosiding Akuntansi.

Marks, J. (2012). The Mind Behind The Fraudsters Crime : Key Behavioral and Environmental Elements. Crowe Horwath LLP, 1-62. www.crowe.com

Noor, N. F. M., Sanusia, Z. M., Heang, L. T., Iskandar, T. M., \& Isa, Y. M. (2015). Fraud Motives and Opportunities Factors 
on Earnings Manipulations. Procedia Economics and Finance. https://doi.org/10.1016/s2212-5671(15)01091-6

Nurbaiti, Z., \& Hanafi, R. (2017). Analisis Pengaruh Fraud Diamond Dalam Mendeteksi Tingkat Accounting Irregularities. Jurnal Akuntansi Indonesia, 6(2), 167-184. https://doi.org/10.30659/jai.6.2.167-184

Pasaribu, R. B. F., \& Kharisma, A. (2018). Fraud Laporan Keuangan Dalam Perspektif Fraud Triangle. Jurnal Riset Akuntansi Keuangan, 14(1), 53-65.

Pham, N. K., Duong, H. N., Pham, T. Q., \& Ho, N. T. T. (2017). Audit Firm Size, Audit Fee, Audit Reputation and Audit Quality: The Case of Listed Companies in Vietnam. Asian Journal of Finance \& Accounting, 9(1), 429. https://doi.org/10.5296/ajfa.v9i1.10074

Putriana, M., Artati, S., \& Utami, V. J. (2018). Pengaruh Corporate Social Responsibility Terhadap Manajemen Laba Dengan Leverage Dan Growth Sebagai Variabel Control Pada Industri Farmasi Yang Terdaftar Di Bursa Efek Indonesia. J-MAS (Jurnal Manajemen Dan Sains), 3(2), 226. https://doi.org/10.33087/jmas.v3i2.60

Putriasih, K. (2016). Analisis Fraud Diamond Dalam Mendeteksi Financial Statement Fraud : Studi Empiris Pada Perusahaan Manufaktur Yang Terdaftar Di Bursa Efek Indonesia (Bei) Tahun 2013-2015. E-JournalS1 Ak Universitas Pendidikan Ganesha, 6(3).

Rahayu, S., Irwansyah, \& Kurniawan, I. S. (2019). Pengaruh Ukuran Perusahaan, Debt To Equity Ratio, Growth Opportunity, Dan Umur Listing Perusahaan Terhadap Pengungkapan Good Corporate Governance Pada Perusahaan Manufaktur Yang Terdaftar Di Bursa Efek Indonesia (BEI). Jurnal Ilmu Akuntansi Mulawarman (JIAM), 3(3). https://doi.org/http://dx.doi.org/10.29264/jiam.v3i3.2778.

Ratnasari, E., \& Solikhah, B. (2019). Analysis of Fraudulent Financial Statement: The Fraud Pentagon Theory Approach. Gorontalo Accounting Journal, 2(2), 98-112.

Rengganis, R. M. Y. D., Sari, M. M. R., Budiasih, I. G. A. ., Wirajaya, I. G. A., \& Suprasto, H. B. (2019). The fraud diamond: element in detecting financial statement of fraud. International Research Journal of Management, IT and Social Sciences, 6(3), 1-10. https://doi.org/10.21744/irjmis.v6n3.621

Rukmana, H. S. (2018). Pentagon Fraud Affect on Financial Statement Fraud and Firm Value. South East Asia Journal of Contemporary Business, 16(5), 118-122.

Saputra, A. R., \& Kesumaningrum, N. D. (2017). Analisis Faktor - Faktor Yang Mempengaruhi Fraudulent Financial Reporting Dengan Perspektif Fraud Pentagon Pada Perusahaan Perbankan Yang Terdaftar Di Bursa Efek Indonesia Tahun 20112015. Jurnal Akuntansi Dan Keuangan, 22(2), 121-134.

Sasongko, N., \& Wijayantika, S. F. (2019). Faktor Resiko Fraud Terhadap Pelaksanaan Fraudulent Financial Reporting (Berdasarkan Pendekatan Crown's Fraud Pentagon Theory). Riset Akuntansi Dan Keuangan Indonesia, 4(1), 67-76. https://doi.org/10.23917/reaksi.v4i1.7809

Seetharaman, P. (2020). Business models shifts: Impact of Covid-19. International Journal of Information Management, 54(June), 1-4. https://doi.org/10.1016/j.ijinfomgt.2020.102173

Septriyani, Y., \& Handayani, D. (2018). Mendeteksi Kecurangan Laporan Keuangan dengan Analisis Fraud Pentagon. Jurnal Akuntansi, Keuangan Dan Bisnis, 11(1), 11-23. http://jurnal.pcr.ac.id

Setiawati, E., \& Baningrum, R. M. (2018). Deteksi Fraudulent Financial Reporting Menggunakan Analisis Fraud Pentagon : Studi Kasus Pada Perusahaan Manufaktur Yang Listed Di Bei Tahun 2014-2016. Riset Akuntansi Dan Keuangan Indonesia, 3(2), 91-106. https://doi.org/10.23917/reaksi.v3i2.6645

Siddiq, F. R., Achyani, F., \& Zulfikar. (2017). Fraud Pentagon Dalam Mendeteksi Financial Statement. Seminar Nasional Dan the 4Th Call Syariah Paper.

Sigala, M. (2020). Tourism and COVID-19: Impacts and implications for advancing and resetting industry and research. Journal of Business Research, 117(1), 312-321. https://doi.org/10.1016/j.jbusres.2020.06.015

Sihombing, K. S., \& Rahardjo, S. N. (2014). Analisis Fraud Diamond Dalam Mendeteksi Financial Statement Fraud: Studi Empiris Pada Perusahaan Manufaktur Yang Terdaftar Di Bursa Efek Indonesia (BEI) Tahun 2010-2012. Diponegoro Journal Of Accounting, 03(02), 1-12.

Skousen, C. J., Smith, K. R., \& Wright, C. J. (2009). Detecting and predicting financial statement fraud: The effectiveness of the fraud triangle and SAS No. 99. Advances in Financial Economics, 13, 53-81. https://doi.org/10.1108/S15693732(2009)0000013005

Sunardi, S., \& Amin, M. N. (2018). Fraud detection of financial statement by using fraud diamond perspective. International Journal of Development and Sustainability, 7(2), 878-891.

Suparmini, N. K., Ariyanto, D., \& Wistawan, I. M. A. P. (2020). Pengujian Fraud Diamond Theory Pada Indikasi Financial Statement Fraud Di Indonesia. E-Jurnal Akuntansi, 30(6), 1441-1457. https://doi.org/10.24843/EJA.2020.v30.i06.p08

Tessa, C. (2016). Fraudulent Financial Reporting Pengujian Teori Fraud Pentagon pada Sektor Keuangan dan Perbankan di Indonesia. Simposium Nasional Akuntansi.

Tiffani, L., \& Marfuah, M. (2015). Deteksi financial statement fraud dengan analisis fraud triangle pada perusahaan manufaktur yang terdaftar di bursa efek Indonesia. Jurnal Akuntansi \& Auditing Indonesia, 19(2), 112-125. https://doi.org/10.20885/jaai.vol19.iss2.art3

Triyanto, D. N. (2019). Fraudulence Financial Statements Analysis using Pentagon Fraud Approach. Journal of Accounting Auditing and Business, 2(2), 26. https://doi.org/10.24198/jaab.v2i2.22641

Tugas, F. (2012). Exploring A New Element of Fraud: A Study on Selected Financial Accounting Fraud Cases in The World. American International Journal of Contemporary Research, 2(1), 112-121.

Ulfah, M., Nuraina, E., \& Wijaya, A. L. (2017). Pengaruh Fraud Pentagon dalam Mendeteksi Fraudulent Financial Reporting 
(Studi Empiris pada Perbankan di Indonesia yang Terdaftar di BEI). Paper Dipresentasikan Di Forum Ilmiah Pendidikan Akuntansi.

Vivianita, A., \& Indudewi, D. (2019). Financial Statement Fraud Pada Perusahaan Pertambangan Yang Dipengaruhi Oleh Fraud Pentagon Theory (Studi Kasus Di Perusahaan Tambang Yang Terdaftar Di BEI Tahun 2014-2016). Jurnal Dinamika Sosial Budaya, 20(1), 12-29. https://doi.org/10.26623/jdsb.v20i1.1229

Wahyuningrum, L., \& Iswajuni. (2020). The factors affecting fraudulent financial reporting in the fraud triangle perspective. International Journal of Innovation, Creativity and Change, 11(9), 314-328.

Weiner, J. (2012). Auditor Size vs. Audit Quality: An Analysis of Auditor Switches. Accounting.

Wicaksono, K. W. (2015). Akuntabilitas Organisasi Sektor Publik. JKAP (Jurnal Kebijakan Dan Administrasi Publik), 19(1), 17-26. https://doi.org/10.22146/jkap.7523

Wolfe, D. T., \& Hermanson, D. R. (2004). The Fraud Diamond: Considering the Four Elements of Fraud. CPA Journal, 74(12), 38-42.

Yateno, \& Sari, G. P. (2016). Penguji Manipulasi Laba Real Pada Pengungkapan Corporate Social Responsibility (Studi Empiris Pada Perusahaan Manufaktur Di Bursa Efek Indonesia). Jurnal Akuisisi, 12(2), $26-36$. https://doi.org/10.24127/akuisisi.v12i2.106

Yendrawati, R., Aulia, H., Prabowo, H. Y., Indonesia, U. I., Indonesia, U. I., \& Indonesia, U. I. (2019). Detecting the Likelihood of Fraudulent Financial Reporting : March 2019.

Yusof, K. M. (2015). Fraudulent Financial Reporting: An Application of Fraud Models to Malaysian Public Listed Companies. The Macrotheme Review, 4(3), 126-145.

Zaki, N. M. (2017). The Approriateness Of Fraud Triangle And Diamond Models In Assessing The Likelihood Of Fraudulent Financial Statements-An Empirical Study on Firms Listed In The Egytian Stock Exchange. International Journal of Social Science and Economic Research, 2(2), 2403-2433.

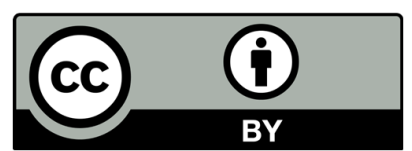

(C) 2021 by the authors; licensee Growing Science, Canada. This is an open access article distributed under the terms and conditions of the Creative Commons Attribution (CC-BY) license (http://creativecommons.org/licenses/by/4.0/). 